\title{
Ocular Adnexal Lymphoma pM1a TNM
} Finding v7

National Cancer Institute

\section{Source}

National Cancer Institute. Ocular Adnexal Lymphoma pM1a TNM Finding v7. NCI

Thesaurus. Code C88855.

Noncontiguous involvement of tissues or organs external to the ocular adnexa (e.g., parotid gland, submandibular gland, lung, liver, spleen, kidney, breast, etc.). (from AJCC 7th Ed.) 